\title{
Antitumor and immunomodulatory activity of Inonotus obliquus
}

\author{
JUSTYNA STANISZEWSKA ${ }^{1}$, MARCIN SZYMAŃSKI ${ }^{1, *}$, EWA IGNATOWICZ ${ }^{2}$
}

\author{
${ }^{1}$ Department of Pharmacognosy \\ Poznan University of Medical Sciences \\ Święcickiego 4 \\ 60-781 Poznań, Poland \\ ${ }^{2}$ Department of Pharmaceutical Biochemistry \\ Poznan University of Medical Sciences \\ Święcickiego 4 \\ 60-781 Poznań, Poland \\ *corresponding author: phone: +48 6185467 03, e-mail: mszymanski@ump.edu.pl
}

\section{Summary}

The article presents the antitumor and immunomodulatory activity of compounds and extracts from Inonotus obliquus. Polysaccharides isolated from sclerotium have a direct antitumor effect due to protein synthesis inhibition in tumor cells. Polysaccharides derived from the mycelium function by activating the immune system. Due to the limited toxicity of these substances, both extracts as well as isolated and purified chemicals may be a good alternative to current chemotherapy and play a role in cancer prevention. In vitro experiments have shown the inhibition of inflammation with the influence of action of I. obliquus extracts; however, in vivo experiments on animals implanted with tumor cells of different types have shown the activation of the host immune system. This led to decrease in tumor mass and prolonged survival. The immunomodulatory mechanism of action is complex and it seems that stimulation of macrophages and induction of apoptosis in cancer cells is of great importance.

Key words: Inonotus obliquus, chaga, antitumor activity, immunomodulatory activity

\section{INTRODUCTION}

Systematics of Inonotus obliquus (Chaga mashroom) according to Index Fungorum is as follows: Inonotus obliquus (Fr.) Pilát, Inonotus, Hymenochaetaceae,
Hymenochaetales, Incertae sedis, Agaricomycetes, Agaricomycotina, Basidiomycota, Fungi.

Chaga occurs in Russia, Scandinavia, Europe, North America and Asia. It is found mainly in forests and less frequently in parks throughout whole 
year. It is a 'wound parasite' that causes white uniform rot on an occupied tree $[1,2]$.

Fruiting bodies are found in the gender form (excellent) and in the asexual one (imperfect, vegetative). The fruiting bodies of vegetative forms of the asexual form develop a growth (dark brown, cracked, resembling coke) on the trunk of a living tree. The process of formation of growths is long-lasting, gradual, and the wood being near these fruiting bodies grows strongly, like the trunk. The flesh of this fungus forms hard and firm mycelium; it is initially yellowish-ochre in color and darkens with age to brown, with a whitish, marbled pattern. Every year, fruiting bodies produce chlamydospores, which are the spore forms. Chlamydospores are 1-4-cell, oval, with thick cell walls, of olive-brown color. Fruiting bodies of the gender form (perfect) are annual, not typical, located near the vegetative fruiting bodies. They appear along the trunk - between the wood and the bark or between the layers of wood. In the early stages of development, fruiting bodies of the gender form are soft, next fleshy, and when ripe, they become corky and brittle. The dimensions of the mature fruiting bodies may reach several meters in length, but they are quite narrow (a dozen of centimeters) and thin (up to $10 \mathrm{~mm}$ of thickness). A hymenophore makes almost the entire thickness of the fruiting body. It is tubular, whitish, and darkens with age; the tubes are arranged diagonally in a single layer, $10 \mathrm{~mm}$ of length. Fruiting bodies of the gender forms have a concentration of mycelium on the edges, which creates numerous gaps and cracks in the trunk of a tree - so the sow of spores and the further growth of the fungus are possible. Spores are colorless and a rash is white [2].

The fungus is used in the Russian folk medicine in the treatment of inoperable breast cancer, oral cancer, gastrointestinal cancer, parathyroid, lung and skin cancer as well as Hodgkin's disease [1].

Most often it can be found on trees such as Betula pendula, B. pubescens, B. carpatica, and Fagus sylvatica; less frequently it occurs on Acer campestre, A. pseudoplatanus, Alnus glutinosa, A. incana, Fraxinus excelsior, Quercus cerris, Q. petraea, Q. robur, Q. delachampii, and Ulmus sp. [3].

Most research on the pharmacological activity of the fruiting bodies of this fungus has been carried out in the research centers in Germany, Japan, Korea and the Republic of China. Fruiting bodies of this fungus are rich sources of various biologically active compounds, such as polysaccharides [4-13], phenolic compounds [14-16], triterpenes [17-20], betulin and betulinic acid [21], ergosterol and ergosterol peroxide [22], inotodiol [23], and melanin [24]. Research have shown that extracts of Inonotus obliquus indicate the anti-inflammatory [25-27], immunomodulatory $[5,28-30]$, anticancer $[10,19$, 20, 31-39], antiviral [40, 41], anti-platelet [42], antiallergic [43] and antidiabetic activity [44, 45].

\section{Biological activity of active compounds isola- ted from Inonotus obliquus}

\section{Polysaccharides}

Among compounds of this type, heteropolysaccharides and homoglucans isolated from the fruiting bodies (sclerotia) as well as endo-polysaccharides present in the mycelium can be distinguished. The compounds differ in the mechanism of antitumor activity; polysaccharides from fruiting bodies act directly on the tumor cells [46] and endo-polysaccharides act indirectly by activating the immune system in a way similar to bacterial lipopolysaccharide (LPS). A specific inhibitor of LPS, polymyxin $B$, does not affect the activation properties of endopolysaccharide, which suggests the involvement of different localizations in the structure of a molecule that bind to the receptors of immunocompetent cells. B-cells exposed to endo-polysaccharide increased the production of $\operatorname{IgM}$ and macrophages generated higher amounts of nitrogen oxide and showed the increased expression of genes encoding the proinflammatory cytokines IL- $1 \beta$, IL- 6 and TNF- $\alpha$, and inducible nitric oxide synthase (iNOS) as well. The observed changes in the immune cells were dependent on the dose; there was no further activation of T-cells [5].

Kim Yong Ook et al. characterized the isolated endo-polysaccharide as $\alpha$-fucoglucomannan. In in vitro studies this compound showed no cytotoxicity to normal model and cancer human cell lines and increased proliferation of macrophages. In in vivo studies in mice implanted with melanoma B16-F10 cell line, almost four-time improvement of survival of animals receiving intraperitoneal endo-polysaccharide formulation at a dose of $30 \mathrm{mg} / \mathrm{kg} /$ day compared with control group was found. Oral administration of the preparation was characterized by lower antitumor activity. The authors of the research suggest that the endo-polysaccharide is responsible for the antitumor effect by activating the host immune system rather than by direct cytotoxicity [47]. 


\section{Triterpenoids}

Among researched triterpenoids, inotodiol (fig. 1) showed the strongest anti-proliferative effect on breast cancer Walker 256 cell line, the lower effect was indicated by trametenolic acid (fig. 2). The antiproliferative effect is about the activation of caspase 3 and apoptosis induction as well as the inhibition of the process of synthesis in the $S$ phase of the cell cycle. Furthermore, inotodiol, in a dose- and timedependent exposure, decreased the expression of Ki-67 antigen, a marker of mitotic cell activity [48].

The sclerotia of $I$. obliquus were extracted with chloroform. The chloroform solution was evaporated under reduced pressure. The resulting residue was subjected to silica gel column chromatography. In in vivo experiments, inotodiol significantly prolonged the survival period of mice with skin papillomas induced with dimethylbenzanthracene (fig. 3) and phorbol ester (fig. 4) action. At the same time, there were no side effects in animals such as diarrhea and weight loss [49]. In the culture of murine leukemia P388 cell lines, trametenolic acid significantly reduced proliferation and inotodiol showed less activity [50].

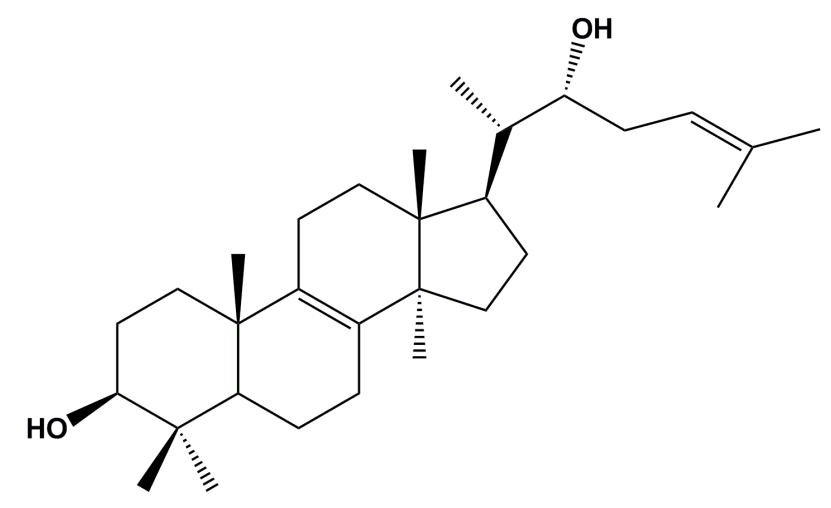

Figure 1.

Structure of inotodiol

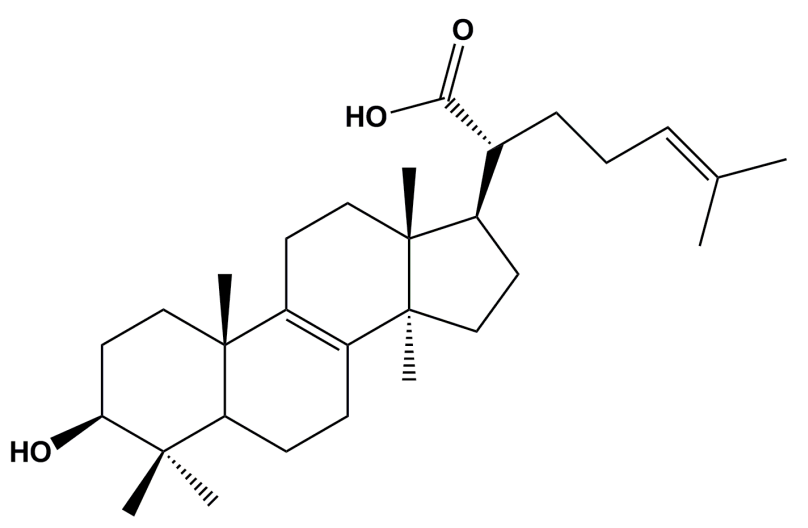

Figure 2.

Structure of trametenolic acid<smiles>Cc1c2ccccc2c(C)c2c1ccc1ccccc12</smiles>

Figure 3.

Structure of dimethylbenzanthracene

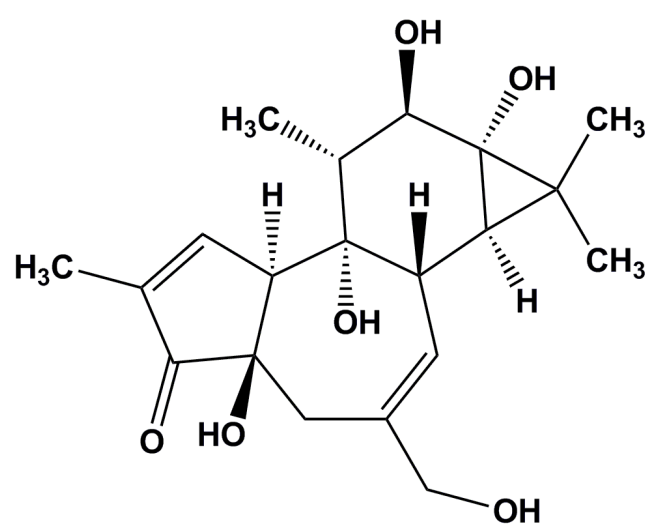

Figure 4.

Structure of phorbol ester

Benzyl alcohol

Benzyl alcohol (fig. 5) has the ability to solubilize the cell membrane, but that interaction with the lipid bilayer is not decisive for its anti-proliferative activity. Benzaldehyde, benzyl alcohol metabolite, is responsible for this effect. This compound develops during the cell metabolism or a spontaneous autoxidation process, which may be accelerated by the presence of reactive oxygen associated with carcinogenesis [51].<smiles>OCc1ccccc1</smiles>

Figure 5.

Structure of benzyl alcohol

Ergosterol

The dried Chaga were extracted with 95\% ethanol. The extract was filtered and evaporated. This ethanol 
extract was then suspended in distilled water and partitioned with $n$-hexane.

Ergosterol peroxide (fig. 6) acts as an antiproliferative agent and also inhibits the colony formation ability of tumor cells HCT116, HT-29, SW620 and DLD-1 cell lines of the colon. This inhibition of growth is due to the induction of apoptosis and lowering the concentration of $\beta$-catenin, which, in turn, reduces the expression of c-Myc, D1 cyclin, and Cdk-8 kinase, the proteins that activate cell proliferation. In mice with induced colon cancer with azoxymethane and dextran sulfate sodium administration, the reduction in the expression of $\mathrm{Ki}$ 67 antigen was observed. The authors suggest that ergosterol peroxide can be used in the prevention of colorectal cancer [22].

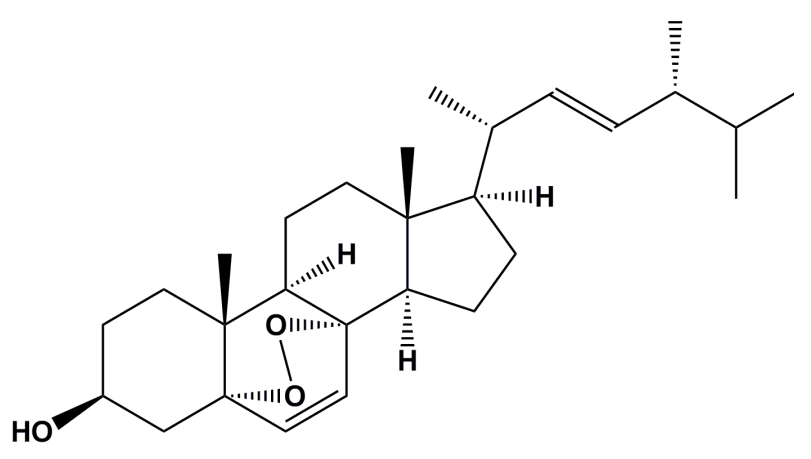

Figure 6.

Structure of ergosterol peroxide

\section{Mechanisms of antitumor activity of extracts of Inonotus obliquus. Research on tumor cells in culture}

Oxidative stress, induced by toxic and carcinogenic xenobiotics and accompanying inflammatory diseases, leads to the presence of significant amounts of reactive oxygen (ROS) and nitrogen (RNS) species. These substances may be free radicals or not, but their common characteristic is the ability to damage the structure of proteins, polysaccharides, lipids, and nucleic acids. Aerobic degradation of DNA is considered to be a major cause of carcinogenic mutations, so, the substances that act as antioxidants are of value in the prevention of cancer and other degenerative diseases such as arteriosclerosis, cataracts, and Alzheimer's disease $[52,53]$.

$\mathrm{Hu}$ et al., studying ethanol and water extracts of I. obliquus found significant antioxidant activity measured in vitro in the radical 1,1-di- phenyl-2-picrylhydrazyl reduction test. Furthermore, the ethanol extract decomposed superoxide radical anion in a manner similar to superoxide dismutase. In the research on human cells of colon carcinoma DLD-1 line, the ethanol extract demonstrated the ability to inhibit proliferation and induce apoptosis; the aqueous extracts did not have these characteristics [54].

Different results were obtained by Burczyk et al. culturing cervical HeLa cancer cells with an aqueous extract of I. obliquus. A significant decrease in the protein synthesis and the inhibition of proliferation due to the accumulation of cells in G1/G0 were observed [55].

The mixture of endo-polysaccharides contained in the aqueous mycelium extract significantly and dose-dependently inhibited spontaneous and induced activity of $\mathrm{Fe}(\mathrm{II})$, lipid peroxidation and mitochondrial damage in mouse hepatocytes in vitro. The extract added to the culture of SMMC7721 liver cancer cell line inhibited the proliferation. It was also found that the extract in the amount of $150 \mathrm{mg} / \mathrm{ml}$ gives an inhibitory effect comparable to that of $5 \mu \mathrm{g} / \mathrm{ml}$ of mitomycin. Corresponding experiments with the extract of the fruiting bodies exhibited a superior anti-tumor activity of the mycelium extract [56].

The cytotoxicity of the water extract of I. obliquus has been also researched in cultured human hepatoma HepG2 and Hep3B cell lines and immortalized normal liver Chang cell line. The inhibition of growth in all cell lines was dose-dependent; Chang cells were the least sensitive to the cytotoxic effects of the extract and HepG2 cell line - the most. Due to selective effects of I. obliquus extract on HepG2 cells, further investigation of cell cycle and protein levels modulating the cycle was performed. Using flow cytometry, the cell cycle arrest was observed in the G0/G1 phase and the reduced number of cells in $\mathrm{S}$ phase. The cycle arrest in the G0/G1 phase enables a cell to repair damaged DNA or to start the process of apoptosis - programmed cell death. In the described experiment, the effect of the aqueous extract of I. obliquus on apoptotic cell death by activation of caspase-3, a key enzyme for this process, was observed. Furthermore, the reduced levels of cell cycle regulatory proteins, p53, p27 and pRB, were observed. In HepG2 cells cultured in the presence of the extract of I. obliquus, the inhibition of the transition from G1 to $S$ phase corresponds to the down-regulation of cyclins and cyclin-dependent kinases. The largest reduction was observed in the case of cyclin D1 kinases 
Cdk2 Cdk6, and cyclins D2 and E and Cdk4 kinase were less responsive to the I. obliquus extract. The authors continued the research of cytotoxicity of the aqueous extract of I. obliquus in B16-10 cell line, mouse melanoma. The dose-dependent significant reduction in proliferation as well as the induction of differentiation of melanoma cells were observed. As in case of HepG2 [31], the accumulation of cells in G0/G1 phase and the decrease in cells in S phase cells were stated. In B16-10 cells, the induction of apoptosis under the influence of action of the aqueous extract of I. obliquus was also confirmed; a dose-dependent increase in caspase- 3 activity was found. The cycle arrest in the G0/G1 phase is also associated with lowering the levels of the key regulators of the cell cycle progression: $\mathrm{p} 53, \mathrm{pRb}$ and $\mathrm{p} 27$ proteins, D1 and E cyclins as well as and cyclin-dependent kinases Cdk2 and Cdk4 in tumor cells treated with the extract of I. obliquus [32].

In the process of cancer prevention, the immune system activity and the modulation of factors that influence the inflammatory response are also important. Chronic inflammation is a process of generating ROS and RNS, among others by cyclooxygenase-2 (COX-2) enzymes and inducible nitric oxide synthase (iNOS) [57]. COX-2 catalyzes the formation of inflammatory mediators (prostaglandins and thromboxanes) and prostacyclins from arachidonic acid and iNOS is responsible for the synthesis of massive amounts of nitric oxide (NO), which together with ROS form prooxidative environment. Macrophages are the cells of the innate immune activation of responding iNOS and COX-2 on pro-inflammatory factors. The expression of genes encoding these enzymes is regulated by NFKB transcription factor, translocation of which to the nucleus activates a signaling cascade leading to inflammation [58]. The results of the research of Ko et al. [35] pay attention to the modulation of the immune system due to I. obliquus extract. In mice that had induced allergies using ovalbumin, oral administration of the aqueous extract showed reduced secretion of interleukin- 4 and the increased level of interferon- $\gamma$ (IFN- $\gamma$ ), which suggest strengthening responses from the Th1 cells promoting a cellular response and the inhibition of Th2 cells, supporting the humoral immunity. Macrophages isolated from the peritoneal cavity of mice and stimulated with bacterial lipopolysaccharide (LPS) due to I. obliquus extract, generated less NO, and, on the other hand, increased the synthesis of tumor necrosis factor- $\alpha$ (TNF- $\alpha$ ). There has been also the reduction in the total levels of IgE and IgG2a as well as immunization of ovalbumin - specific IgE and IgG1 antibodies. This phenomenon is consistent with the experiment described in the inhibition of the activity of Th2. T-cells isolated from CD4 + mouse spleen, were subjected to the mitogen action of concanavalin A (ConA) and the decreased secretion of interleukin- 2 and -4 , and IFN- $\gamma$ was observed. The authors suggest that I. obliquus extract indicates anti-inflammatory and antiallergic activity.

In studies on the effect of the methanol extract of I. obliquus on a pro-inflammatory effect of stimulating murine macrophage RAW 264.7 LPS cell line, there was a significant reduction in the levels of generated $\mathrm{NO}$ and the concentration of prostaglandin E2 (PGE2) and TNF- $\alpha$. These observations were confirmed by the analysis of the gene expression of iNOS and COX-2 and the concentration of the corresponding enzyme proteins. Furthermore, the methanol extract of I. obliquus significantly inhibited combining NFKB transcription factor with DNA [25].

In a similarly designed experiment using RAW 264.7 macrophages stimulated by LPS, the effect of I. obliquus extract obtained with $70 \%$ ethanol on the activity of COX-2 and iNOS was investigated. A significant and dose-dependent decrease in NO production and the expression of COX-2 and iNOS in LPS-stimulated macrophages were observed. The analysis of the mechanisms of this phenomenon has revealed, that it is dependent on the suppression of NFkB and protein kinase B (Akt), which is one of the key factors that promotes cell proliferation, cell migration, and angiogenesis. The authors suggest that a combination of these characteristics of I. obliquus extract is a great value of raw material as antimutagenic anti-inflammatory, and analgesic preparation [59].

\section{Mechanisms of antitumor activity of extracts of Inonotus obliquus. Research in animal mo- dels}

The anti-inflammatory effects of the methanol extract of I. obliquus were demonstrated in a model of the acute paw swelling, caused by the subcutaneous administration of carrageenan induced in a rat. It has been found that the extract's effect is dose-dependent (100 and $200 \mathrm{mg} / \mathrm{kg}$ body weight), but has moderate anti-inflammatory 
activity as compared with ibuprofen. In additional assays involving induction of pain in mice, moderate analgesic activity of $I$. obliquus extract was confirmed in comparison with aspirin and morphine [25].

In order to investigate whether the extract of mycelium of I. obliquus has an inhibitory effect on tumor growth in vivo, Balb/c mice were inoculated with melanoma B16-F10 cell line. The aqueous extract was administered to mice orally or by intraperitoneal injection. In the control group and in animals that received the extract prior to inoculation of cancer, weight gain associated with an increased mass and the number of tumors was observed, while the mice treated with the extract after the inoculation no changes in body weight were measured, compared with the control. The data analysis also showed that intraperitoneal administration has a stronger antitumor effect than oral one. The authors further suggest that the observed anti-tumor activity in vivo of the aqueous extract of I. obliquus, may be the result of not only the activation of the immune system of the host, but also the result of the direct effect of the extract on tumor cells or other mechanisms [32].

In mice inoculated subcutaneously with mouse sarcoma, Sarcoma 180 (S-180) cell lines, and administered orally in different doses $(20,60$ and $100 \mathrm{mg} / \mathrm{kg}$ ) of an aqueous extract of I. obliquus sclerotium, lymphocyte viability, the weight of the organs of the immune system, thymus and spleen, the tumor mass as well as the expression of proteins produced by $\mathrm{Bax}$ and $\mathrm{Bcl}-2$ genes in tumor cells and the release of tumor necrosis factor- $\alpha$ (TNF- $\alpha$ ) from lymphocytes from the peritoneal cavity of mice were examined. At the same time, the impact of I. obliquus extract on the S-180 cells was examined in vitro. 14 days after tumor implantation, a decrease in the number and capacity of lymphocyte proliferation and decrease in the release of TNF- $\alpha$ from the lymphocyte were found, compared with the results of the control animals and the administration of $I$. obliquus extract in a dose-dependent manner restored the extend of these parameters to the level observed in control. In vitro experiment using flow cytometry showed the accumulation of S-180 cells in G1/M and S phases, and a small percentage of apoptotic cells in the G0/G1 phase. Under the influence of action of $I$. obliquus extract, the reduction in the proliferation of S-180 caused by the accumulation of cells in G1/G0 phase as well as the apoptotic ones was observed; this effect was dose-dependent. The tumor mass was smaller in mice treated with the extract of I. obliquus. Histochemical examination of tumor pieces showed down-regulation of the pro-apoptotic products of Bax gene and increased the expression of anti-apoptotic Bcl-2 gene. The administration of the extract to mice with implanted tumor reversed these relations. On the basis of the results obtained, the authors of the research suggest, that the effect of the aqueous extract of I. obliquus protects lymphocytes destroyed by the cancerous process, intensifies the immune defense against S-180 cells and leads to apoptosis of tumor cells in vivo, among others, by an increase in TNF$\alpha$-cell lymphoma [33].

In similarly planned experiment in mice implanted with S-180 cells, comparable results for the immunomodulating activity of I. obliquus were obtained. It was also found that the extract containing soluble alkaline polysaccharide stimulates macrophages to increased secretion of nitric oxide by increasing the activity of inducible nitric oxide synthase. Increasing the phagocytic activity of macrophages confirmed with the high activity of lysosomal enzymes suggests, that the mechanism of immunomodulation involves the non-specific immune reactions associated with the induction of inflammation as well. Activated macrophages are important factors in the immune system of the host and the nitrogen oxide as an effector molecule is involved not only in killing tumor cells, but also in defense against bacteria, fungi, and parasites. The extract from fungus was subjected to the structural analysis, which showed the presence of rhamnose, xylose, mannose, galactose, glucose, and galacturonic acid [60].

Preparation comprising a mixture of the powdered mycelium (Phellinus linteus, Inonotus obliquus, Antrodia camphorate, and Ganoderma lucidum) was administered intraperitoneally to mice injected with the mouse melanoma B16-F10 cell line, which developed solid tumors in the peritoneal cavity; doxorubicin therapy was used as a comparison. Oral administration of $300 \mathrm{mg} / \mathrm{kg}$ of body mass per day decreased tumor mass in a manner comparable to the results for animals treated with doxorubicin and approx. in 50\% increased the survival time in comparison to animals treated with either doxorubicin or the mycelium powder. By studying the mechanism of this phenomenon, the authors found out that the inhibition of B16F10 cells proliferation occurs by the cell cycle arrest in G0/G1 phase, inhibition of the expression of D1 cyclin and cyclin-dependent kinases (Cdk4 and 
Cdk2), and the induction of $\mathrm{p} 21$ protein, which indicates the activation of the apoptosis process [61].

\section{CONCLUSION}

Heteropolysaccharides and homoglucans isolated from the fruiting bodies (sclerotia) as well as endopolysaccharides present in the mycelium differ in the mechanism of antitumor activity; polysaccharides from fruiting bodies act directly on the tumor cells and endo-polysaccharides act indirectly by activating the immune system in a way similar to bacterial lipopolysaccharide.

Among the researched triterpenoids, inotodiol showed the strongest anti-proliferative effect on breast cancer Walker 256 cell line, the lower effect was indicated by trametenolic acid.

Benzyl alcohol has the ability to solubilize the cell membrane, but that interaction with the lipid bilayer is not decisive for its anti-proliferative activity. Benzaldehyde, benzyl alcohol metabolite, is responsible for this effect.

Ergosterol peroxide acts as an antiproliferative agent and also inhibits the colony formation ability of tumor cells HCT116, HT-29, SW620 and DLD-1 cell lines of colon.

In the research on human cells of colon carcinoma DLD-1 line, the ethanol extract demonstrated the ability to inhibit proliferation and induce apoptosis; the aqueous extracts did not have these characteristics.

Further research is needed to explain the antitumor activity of I. obliquus and enable widespread adoption of preparations of this fungus to pharmacotherapy.

Ethical approval: The conducted research is not related to either human or animal use.

Conflict of interest: Authors declare no conflict of interest.

\section{REFERENCES}

1. Pilz D. Chaga and Other Fungal Resources. Assessment of Sustainable Commercial Harvesting in Khabarovsk and Primorsky Krais, Russia. PilzWald Forestry Applications of Mycology 2004; 541.753.6209.

2. Łakomy P, Kwaśna P. Atlas hub. Warszawa, 2008.

3. Min-Woong L, Hyeon-Hur, Kwang-Choon C, Tae-Soo L, Kang-Hyeon K, Jankovsky L. Intro- duction to distribution and ecology of sterile conks of Inonotus obliquus. Mycobiology 2008; 36:199-202. doi: http://dx.doi.org/10.4489/ MYCO.2008.36.4.199

4. Mizuno T, Zhuang C, Abe K, Okamoto H, Kiho T, Ukai $S$ et al. Antitumor and hypoglycemic activities of polysaccharides from the sclerotia and mycelia of Inonotus obliquus (Pers.: Fr.) Pil. (Aphyllophoromycetideae). Int J Med Mushrooms 1999; 1(4):301-316. doi: http://dx.doi.org/10.1615/IntJMedMushr.v1.i4.20

5. Kim YO, Han SB, Lee HW, Ahn HJ, Yoon YD, Jung JK et al. Immuno-stimulating effect of the endo-polysaccharide produced by submerged culture of Inonotus obliquus. Life Sci 2005; 77(19):2438-2456. doi: http://dx.doi. org/10.1016/j.lfs.2005.02.023

6. Rhee SJ, Cho SY, Kim KM, Cha DS, Park HJ. A comparative study of analytical methods for alkali-soluble $\beta$-glucan in medicinal mushroom, Chaga (Inonotus obliquus). LWT Food Sci Technol 2008; 41(3):545-549. doi: http://dx.doi. org/10.1016/j.lwt.2007.03.028

7. Xiu-hong Z, Kuang R, Shi-jie L, Shu-yan Y, Dongzhi S. Progress of research on Inonotus obliquus. Chin J Integr Med 2009; 15:156-160. doi: http:// dx.doi.org/10.1007/s11655-009-0156-2

8. Yiyong C, Xiaohong $\mathrm{G}$, Sheng-quan $\mathrm{H}$, Jinwei L, Xin W, Jian T. Optimization of ultrasonic/microwave assisted extraction (UMAE) of polysaccharides from Inonotus obliquus and evaluation of its anti-tumor activities. Int J Biol Macromol 2010; 46:429-435. doi: http://dx.doi.org/10.1016/j. ijbiomac.2010.02.003

9. Sheng-quan H, Shaodong D, Liuping F. Antioxidant activities of five polysaccharides from Inonotus obliquus. Int J Biol Macromol 2012; 50:1183-1187. doi: http://dx.doi.org/10.1016/j. ijbiomac.2012.03.019

10. Ki RL, Jong SL, Young RK, In GS, Eock KH. Polysaccharide from Inonotus obliquus inhibits migration and invasion in B16-F10 cells by suppressing MMP-2 and MMP-9 via downregulation of NFkB signaling pathway. Oncology Reporters 2014; 31:2447-2453. doi: http://dx.doi.org/10.3892/ or.2014.3103 
11. Xu X, Hu Y, Quan L. Production of bioactive polysaccharides by Inonotus obliquus under submerged fermentation supplemented with lignocellulose biomas and their antioxidant activity. Bioproc Biosyst Eng 2014; 37:2483-2492. doi: http://dx.doi.org/10.1007/s00449-014-1226-1

12. Xu X, Quan L, Shen M. Effect of chemicals on production, composition and antioxidant activity of polysaccharides of Inonotus obliquus. Int J Biol Macromol 2015; 77:143-150. doi: http://dx.doi. org/10.1016/j.ijbiomac.2015.03.013.

13. Yiyong C, Youru H, Zhumei C Jingjing L. Purification, characterization and biological activity of a novel polysaccharide from Inonotus obliquus. Int J Biol Macromol 2015; 79:587-594. doi: http:// dx.doi.org/10.1016/j.ijbiomac.2015.05.016

14. In-Kyoung L, Young-Sook K, Yoon-Woo J, JinYoung J, Bong-Sik Y. New antioxidant polyphenols from the medicinal mushroom Inonotus obliquus. Bioorg Med Chem Lett 2007; 17:6678-6681. doi: http://dx.doi.org/10.1016/j. bmcl.2007.10.072

15. Kuriyama I, Nakajima Y, Nishida H, Konishi T, Takeuchi T, Sugawara F. Inhibitory effects of low molecular weight polyphenolics from Inonotus obliquus on human DNA topoisomerase activity and cancer cell proliferation. Mol Med Rep 2013; 8:535-542. doi: http://dx.doi.org/10.3892/ mmr.2013.1547

16. Zheng W, Zhang M, Zhao Y, Miao K, Jiang $H$. NMR-based metabonomic analysis on effect of light on production of antioxidant phenolic compounds in submerged cultures of Inonotus obliquus. Biores Technol 2009; 100:4481-4487. doi: http://dx.doi.org/10.1016/j.biortech.2009.04.027

17. Zheng W, Zhao Y, Zheng X, Liu Y, Pan S, Dai Y et al. Production of antioxidant and metabolites by submerged cultures of Inonotus obliquus cocultured with Phellinus punctatus. Microb Cell Physiol 2011; 89:157-167. doi: http://dx.doi. org/10.1007/s00253-010-2846-2

18. Handa N, Yamada T, Tanaka R. An unusual lanostane-type triterpenoid, spiroinonotsuoxodiol, and other triterpenoids from Inonotus obliquus. Phytochemistry 2010; 71:1774-1779. doi: http:// dx.doi.org/10.1016/j.phytochem.2010.07.005
19. Taji S, Yamada T, Wada SI, Tokuda H, Sakuma K, Tanaka R. Lanostane-type triterpenoids from the sclerotia of Inonotus obliquus possessing antitumor promoting activity. Eur J Med Chem 2008; 43:2373-2379. doi: http://dx.doi.org/10.1016/j.ejmech.2008.01.037

20. Zhao F, Mai Q, Ma J, Xu M, Wang X, Cui T et al. Triterpenoids from Inonotus obliquus and their antitumor activities. Fitoterapia 2015; 101:34-40. doi: http://dx.doi.org/10.1016/j.fitote.2014.12.005

21. Yu JK, Jinseon P, Byung SM, Sang HS. Chemical constituents from the sclerotia of Inonotus obliquus. J Korean Soc Appl Bi 2011; 54:287-294. doi: http://dx.doi.org/10.3839/jksabc.2011.045

22. Kang JH, Jang JE, Mishra SK, Lee HJ. Ergosterol peroxide from Chaga mushroom (Inonotus obliquus) exhibits anti-cancer activity by down-regulation of the $\beta$-catenin pathway in colorectal cancer. J Ethnopharmacol 2015; 173:303-312. doi: http://dx.doi.org/10.1016/j. jep. 2015.07 .030

23. Deyao D, Feng Z, Xianhui C, Xiuyun J, Youjian F, Lian-Wen $Q$ et al. Rapid isolation and purification of inotodiol and tremetenolic acid from Inonotus obliquus by high-speed counter-current chromatography with evaporative light scatting detection. Phytochem Anal 2011; 22:419-423. doi: http://dx.doi.org/10.1002/pca.1297

24. Babitskaia VG, Shcherba VV, Ikonnikova NV. Melanin complex of the fungus Inonotus obliquus. Prikl Biokhim Mikrobiol 2000; 36:439-44.

25. Park YM, Won JH, Kim YH, Choi JW, Park HJ, Lee KT. In vivo and in vitro anti-inflammatory and anti-nociceptive effects of the methanol extract of Inonotus obliquus. J Ethnopharmacol 2005; 101:120-128. doi: http://dx.doi.org/10.1016/j. jep.2005.04.003

26. Choi SY, Hur SJ, An CS, Jeon YH, Jeoung YJ, Bak JP et al. Anti-inflammatory effects of Inonotus obliquus in colitis induced by dextran sodium sulfate. J Biomed Biotechnol 2010; ID 943516: 5 pages. doi: http://dx.doi. org/10.1155/2010/943516

27. Debnath T, Park SR, Kim DH, Jo JE, Lim BO. Anti-oxidant and anti-inflammatory activites of Inonotus obliquus and germinated brown rice ex- 
tracts. Molecules 2013; 18:9293-9304. doi: http:// dx.doi.org/10.3390/molecules18089293

28. Yeon-Ran K. Immunomodulatory activity of the water extract from medicinal mushroom Inonotus obliquus. Mycobiology 2005; 33:158162. doi: http://dx.doi.org/10.4489/MYCO. 2005.33.3.158

29. Harikrishnan R, Balasundaram C, Heo MS. Inonotus obliquus containing diet enhances the innate immune mechanism and disease resistance in olive flounder Paralichythys olivaceus against Uronema marinum. Fish Shellfish Immunolog 2012; 32:1148-1154. doi: http://dx.doi.org/10.1016/j. fsi.2012.03.021

30. Song KC, Choi BL, Shin JW, Son JY, Yoo HS, Cho $\mathrm{JH}$ et al. Effects of Inonotus obliquus extracts on immunomodulating activity. Korean J Orient Med 2007; 28:27-41.

31. Youn MJ, Kim JK, Park SY, Kim Y, Kim SJ, Lee JS et al. Chaga mushroom (Inonotus obliquus) induces G0/G1 arrest and apoptosis in human hepatoma HepG2 cells. World J Gastroent 2008; 14:511-517.

32. Youn MJ, Kim JK, Park SY, Kim Y, Park C, Kim ES et al. Potential anticancer properties of the water extract of Inonotus obliquus by induction of apoptosis in melanoma B16-F10 cells. J Ethnopharmacol 2009; 121:221-228. doi: http://dx.doi. org/10.1016/j.jep.2008.10.016

33. Caifa C, Weifa Z, Xiaowen G, Xiaoyan X. Aqueous extract of Inonotus obliquus (Fr.) Pilat (Hymenochaetaceae) significantly inhibits the growth of sarcoma 180 by inducing apoptosis. Am J Pharmacol Toxicol 2007; 2:10-17. doi: http:// dx.doi.org/10.3844/ajptsp.2007.10.17

34. Wasser SP. Medicinal mushrooms as a source of antitumor and immuno-modulating polysaccharides. Appl Microbiol Biotechnol 2002; 60:258274. doi: http://dx.doi.org/10.1007/s00253-0021076-7

35. Ko SK, Jin M, Pyo MY. Inonotus obliquus extracts suppress antygen-specific IgE production through the modulation of Th1/Th2 cytokines in ovalbumin-sensitized mice. J Ethnopharmacol 2011; 137:1077-1082. doi: http://dx.doi. org/10.1016/j.jep.2011.07.024
36. Sun Y, Yin T, Chen XH, Zhang G, Curtis RB, Lu $\mathrm{ZH}$ et al. In vitro antitumor activity and structure characterization of ethanol extracts from wild and cultivated chaga medicinal mushroom, Inonotus obliquus (Pers.:Fr.) Pilảt (Aphyllophoromycetideae). Int J Med Mushrooms 2011; 13:121-130.

37. Lee SH, Hwang HS, Yun JW. Antitumor activity of water extract of a mushroom, Inonotus obliquus, against HT-29 human colon cancer cells. Phytother Res 2009; 23:1784-1789. doi: http://dx.doi. org/10.1002/ptr.2836

38. Wang Q, Mu H, Zhang L, Dong D, Zhang W, Duan J, Characterization of two water-soluble lignin metabolites with antiproliferative activities from Inonotus obliquus. Int J Biol Macromol 2015; 24:507-514. doi: http://dx.doi. org/10.1016/j.ijbiomac.2014.12.044

39. Xiu-hong Z, Li-bo W, Dong-zhi S. Effects of inotodiol extracts from Inonotus obliquus on proliferation cycle and apoptotic gene of human lung adenocarcinoma cell line A549. Chin J Integr Med 2011; 17:218-223. doi: http://dx.doi. org/10.1007/s11655-011-0670-x

40. Ichimura T, Watanabe O, Maruyama S. Inhibition of HIV-1 protease by water-soluble lignin-like substance from an edible mushroom, Fuscoporia obliqua. Biosci Biotechnol Biochem 1998; 62:575577. doi: http://dx.doi.org/10.1271/bbb.62.575

41. Brandt CR, Piraino F. Mushroom antivirals. Recent Res Dev Antimicrob Agents Chemother 2000; 4:11-26.

42. Kwang WH, Seung CJ, Dae HL, Jeong SP, Jong SL. Isolation and characterization of a novel platelet aggregation inhibitory peptide from the medicinal muchroom, Inonotus obliquus. Peptides 2006; 27:1173-1178. doi: http://dx.doi.org/10.1016/j. peptides.2005.10.005

43. Yoon TJ, Lee SJ, Kim EY, Cho EH, Kang TB, Yu $\mathrm{KW}$ et al. Inhibitory effect of chaga mushroom extract on compound 48/80-induced anaphylactic shock and IgE production in mice. Int Immunopharmacol 2013; 15:666-670. doi: http:// dx.doi.org/10.1016/j.intimp.2013.03.015

44. Lu X, Chen H, Dong P, Fu L, Zhang X. Phytochemical characteristics and hypoglycaemic activity of fraction from mushroom Inonotus 
obliquus. J Sci Food Agr 2010; 90:276-280. doi: http://dx.doi.org/10.1002/jsfa.3809

45. Geng Y, Lu ZM, Huang W, Xu HY, Shi JS, Xu $\mathrm{ZH}$. Bioassay-guided isolation of DPP-4 inhibitory fractions from extracts of submerged cultured of Inonotus obliquus. Molecules 2013; 18:1150-1161. doi: http://dx.doi.org/10.3390/ molecules 18011150

46. Mizuno T, Zhuang C, Abe K, Okamoto H, Kiho T, Ukai S et al. Studies on the host-mediated antitumor polysaccharides. Part XXVII. Mushroom Sci Biotechnol 1996; 3:53-60.

47. Kim YO, Park HW, Kim JH, Lee JY, Moon SH, Shin CS. Anti-cancer effect and structural characterization of endo-polysaccharide from cultivated mycelia of Inonotus obliquus. Life Sci 2006; 79:72-80. doi: http://dx.doi.org/10.1016/j. lfs.2005.12.047

48. Scholzen T, Gerdes J. The Ki-67 protein: from the known and the unknown. J Cell Physiol 2000; 182:311-322. doi: http://dx.doi.org/10.1002/(SICI) 1097-4652(200003)182:3<311::AID-JCP1>3.0.CO; 2-9

49. Nakata T, Yamada T, Taji S, Ohishi H, Wada SI, Tokuda $\mathrm{H}$ et al. Structure determination of inonotsuoxides $\mathrm{A}$ and $\mathrm{B}$ and in vivo anti-tumor promoting activity of inotodiol from the sclerotia of Inonotus obliquus. Bioorg Med Chem 2007; 15:257-264. doi: http://dx.doi.org/10.1016/j.bmc.2006.09.064

50. Nakata T, Taji S, Yamada T, Tanaka R. New lanostane triterpenoids, inonotsutriols $\mathrm{D}$, and $\mathrm{E}$ from Inonotus obliquus. Bull Osaka Univ Pharm Sci 2009; 3:53-64.

51. Mazurkiewicz W, Rydel K, Pogocki D, Lemieszek MK, Langner E, Rzeski W. Separation of an aqueous extract Inonotus obliquus (Chaga). A novel look at the efficiency of its influence on proliferation of A549 human lung carcimona cells. Acta Pol Pharm 2010; 67:397-406.

52. Jakob KD, Noren Hooten N, Trzeciak AR, Evans MK. Markers of oxidant stress that are clinically relevant in aging and age-related disease. Mech Ageing Dev 2013; 134:139-157. doi: http:// dx.doi.org/10.1016/j.mad.2013.02.008
53. Harrison IP, Selemidis S. Understanding the biology of reactive oxygen species and their link to cancer: NADPH oxidases as novel pharmacological targets. Clin Exp Pharmacol Physiol 2014; 41:533-542. doi: http://dx.doi.org/10.1111/14401681.12238

54. Hu H, Zhang Z, Lei Z, Yang Y, Sugiura N. Comparative study of antioxidant activity and antioproliferative effect of hot water and ethanol extracts from the mushroom Inonotus obliquus. J Biosci Bioeng 2009; 1:42-48. doi: http://dx.doi. org/10.1016/j.jbiosc.2008.09.004

55. Burczyk J, Gawron A, Slotwinska M, Smietana B, Terminska K. Antimitotic activity of aqueous extracts of Inonotus obliquus. Boll Chim Farm 1996; 135:306-309.

56. Song Y, Hui J, Kou W, Xin R, Jia F, Wang N et al. Identification of Inonotus obliquus and analysis of antioxidation and antitumor activities of polysaccharides. Curr Microbiol 2008; 57:454462. doi: http://dx.doi.org/10.1007/s00284-0089233-6

57. Hanahan D, Weinberg RA. Hallmarks of cancer: the next generation. Cell 2011; 144:646-674. doi: http://dx.doi.org/10.1016/j.cell.2011.02.013

58. Czyż M, Watała C. Aspiryna - cudowne panaceum? Molekularne mechanizmy działania kwasu acetylosalicylowego $\mathrm{w}$ organizmie. Postępy Hig Med Dośw 2005; 59:105-115.

59. Kim HG, Yoon DH, Kim CH, Shrestha B, Chang WC, Lim SY et al. Ethanol extract of Inonotus obliquus inhibits lipopolysaccharide-induced inflammation in RAW 264.7 macrophage cells. J Med Food 2007; 10:80-89. doi: http://dx.doi. org/10.1089/jmf.2006.156

60. Lixia Z, Cong F, Songchen L, Zhenfeng Z, Lili J, Liping Z. Chemical composition and antitumor activity of polysaccharide from Inonotus obliquus. J Med Plant Res 2011; 5:1251-1260.

61. Park HJ. CARI III inhibitis tumor growth in a melanoma-bearing mouse model through induction of G0/G1 cell cycle arrest. Molecules 2014; 19:14383-14395. doi: http://dx.doi. org/10.3390/molecules190914383 


\title{
Działanie przeciwnowotworowe i immunomodulujące Inonotus obliquus
}

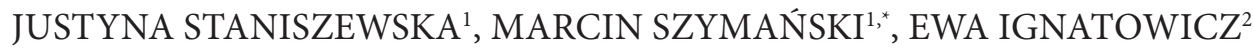

\author{
${ }^{1}$ Katedra i Zakład Farmakognozji \\ Uniwersytet Medyczny im. Karola Marcinkowskiego \\ ul. Święcickiego 4 \\ 60-781 Poznań \\ ${ }^{2}$ Katedra i Zakład Biochemii Farmaceutycznej \\ Uniwersytet Medyczny im. Karola Marcinkowskiego \\ ul. Święcickiego 4 \\ 60-781 Poznań
}

*autor, do którego należy kierować korespondencję: tel.: +48 6185467 03, e-mail: mszymanski@ump.edu.pl

\section{Streszczenie}

W artykule przedstawiono aktywność przeciwnowotworową i immunomodulującą związków i wyciągów z Inonotus obliquus. Polisacharydy izolowane ze skleroty wykazują bezpośrednie działanie przeciwnowotworowe poprzez hamowanie syntezy białek w komórkach nowotworowych. Polisacharydy pochodzące z mycelium działają przez aktywację układu immunologicznego. Ze względu na znikomą toksyczność substancje te, zarówno jako ekstrakty, jak i wyizolowane i oczyszczone związki chemiczne, mogą okazać się dobrą alternatywą dla obecnie stosowanej chemioterapii, a także mieć znaczenie w prewencji nowotworów. $\mathrm{W}$ badaniach in vitro wykazano hamowanie reakcji zapalnych pod wpływem ekstraktów I. obliquus, jednak $\mathrm{w}$ doświadczeniach in vivo, na zwierzętach, którym wszczepiono komórki nowotworowe różnych typów, zaobserwowano aktywację układu immunologicznego gospodarza, co znalazło odzwierciedlenie w zmniejszeniu masy guza i wydłużeniu czasu przeżycia. Mechanizm działania immunomodulującego jest złożony wydaje się, że stymulacja makrofagów i indukcja apoptozy komórek nowotworowych ma znaczenie decydujące.

Słowa kluczowe: Inonotus obliquus, chaga, aktywność przeciwnowotworowa, aktywność immunomodulująca 